\title{
Simulation of Mechanisms Causing Stunting in Northern Pike Populations ${ }^{1}$
}

\author{
James S. Diana \\ School of Natural Resources and Great Lakes Research Division, University of Michigan \\ Ann Arbor, Michigan 48109, USA \\ and \\ Institute for Fisheries Research, Michigan Department of Natural Resources \\ Ann Arbor, Michigan 48109, USA
}

\begin{abstract}
Some mechanisms hypothesized to cause stunting of northern pike Esox lucius include overpopulation and competition, lack of appropriately sized prey, and lack of thermal refuges in midsummer. The objective of this work was to use an energetics model of northern pike growth over 3 years to test the effects of these mechanisms on stunting. Simulations for females indicated the following: (1) competition-based stunting could occur when food resources were reduced by only $5-10 \%$ per individual, such that size at age 3 would be reduced by up to $51 \%$; (2) lack of appropriately sized prey could result in stunting (up to $35 \%$ of a northern pike's annual ration often comes from large and rare prey), such that size at age 3 could be reduced $80 \%$; (3) inappropriate thermal regimes could reduce northern pike growth up to $58 \%$, but only under extremely warm conditions.
\end{abstract}

"Stunting" is a common population characteristic for many species of fish from inland lakes and streams. However, the actual condition of stunting has seldom been studied. Most commonly, fish are considered to be stunted if their growth rate is substantially lower than some arbitrarily defined "normal" for the species (Burrough and Kennedy 1979; Linfield 1979). For the purpose of this paper, stunting will be considered as a reduction in juvenile growth and a near cessation of growth in adulthood. Some salmonids have shown physiological impairment at smolting that may cause individuals to become stunted (Fryer and Bern 1979), but most fish removed from systems in which stunting occurs resume normal growth (Carbine 1944; Reimers 1979). Thus, stunting appears most often to be an ecologically induced condition rather than a genetic one.

Management actions to alleviate stunting include manual removal, water level manipulations, or introduction of predators in order to thin populations (Noble 1980). These actions are based on the premise that populations of stunted fish are a result of high intraspecific or interspecific competition for food that cause reductions in growth. However, these management actions are not always successful (MDNR 1983), indicating that other ecological mechanisms besides competition may also be important to fish stunting.

\footnotetext{
${ }^{1}$ Contribution from Federal Aid in Fish Restoration Project F-35-R, Michigan.
}

Northern pike Esox lucius is a coolwater piscivore that commonly exhibits stunting in lakes. Competition may cause stunting of this species under certain conditions (MDNR 1983), but other factors may also be important. For example, Diana (1979) found that $33 \%$ of the annual energy intake of northern pike in Lac Ste. Anne, Alberta, was due to consumption of large prey items such as white suckers Catostomus commersoni and burbot Lota lota. However, these items were rare in the diet, contributing only $7 \%$ of the total number of prey consumed. Their absence from a lake could lead to stunting.

Another potential cause of stunting may be lack of thermal refuges in midsummer. Northern pike are temperate mesotherms; optimum temperatures for their growth are $18-24^{\circ} \mathrm{C}$ (Casselman 1978; Bevelhimer et al. 1985), a range commonly exceeded in lakes. Northern pike often use the metalimnion of well-oxygenated lakes as a refuge from warm temperatures (Headrick 1985). However, lakes lacking oxygen in the metalimnion, or those too shallow to stratify, may force northern pike to remain at temperatures well above optimum, resulting in reduced ingestion, increased metabolic costs, and reduced or negative growth (Headrick 1985).

A human-induced mechanism that may lead to stunting in northern pike is exploitation, which can reduce age at maturity in many fish species, including northern pike (Healy 1975; Ricker 1981; Diana 1983b). Kempinger and Carline (1978) found that exploitation coupled with minimum- 
size limits led to stunting in a northern pike population. Although reduced fish density due to exploitation may cause competitive release and increased ration, this excess energy available may be shunted into gonad growth due to earlier maturation cited above.

The purpose of my study was to predict the potential of several ecological mechanisms to cause stunting of northern pike. This was accomplished by an energetics modeling approach to predict the size of individual fish under various conditions described previously. A knowledge of mechanisms causing stunting should allow adoption of management actions to alleviate a specific problem, perhaps resulting in a better success rate than is achieved with current management manipulations.

\section{Methods}

The energetics model (from Bevelhimer et al. 1985 ) is based on the balanced energy equation (outlined by Webb 1978), and accounts for ingested energy and energy used for metabolism, specific dynamic action, egestion, and excretion. The difference between ingested energy and energy used is considered to be the growth rate. Specific parameters for the model were take from relevant literature on northern pike metabolism.

Standard metabolism was estimated by the equation

$$
M=33.36 W^{-0.18} e^{0.055 T} ;
$$

$M$ is standard metabolism $(\mathrm{J} / \mathrm{g} \cdot \mathrm{d}), W$ is wet body weight $(\mathrm{g})$, and $T$ is temperature $\left({ }^{\circ} \mathrm{C}\right)$. Maximum food consumption was estimated by the equation

$$
C=0.1021 W^{-0.18} e^{-0.024 T} e^{0.0125 T^{2}} e^{-0.000326 T^{3}} ;
$$

$C$ is consumption $(\mathrm{J} / \mathrm{g} \cdot \mathrm{d})$. Both of these equations were taken from Bevelhimer et al. (1985). Specific dynamic action $(\mathrm{J} / \mathrm{g} \cdot \mathrm{d})$ was considered to be $0.1042 C$, and egestion $(\mathrm{J} / \mathrm{g} \cdot \mathrm{d}$ ) to be $0.13 C$ (both from Diana 1982). Excretion (J/g $\cdot d)$ was estimated as $0.079 C$ (Brett and Groves 1979), while calorific equivalent ( $\mathrm{J} / \mathrm{g}$ wet weight) was 4.780 (Diana and Mackay 1979).

The population of northern pike from Lac Ste. Anne, Alberta, was chosen for simulation because of the energetics data set available for it. Comparisons of size at age for these northern pike to other values indicate that the growth rate is about average for Michigan northern pike populations (Laarman et al. 1981), is intermediate between rates for a variety of latitudes (Miller and Kennedy 1948 ), and is slightly (15\%) higher than values

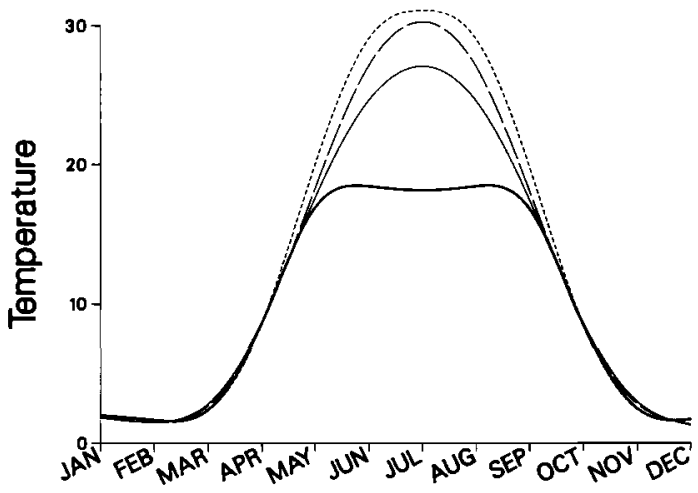

Figure 1.-Temperature $\left({ }^{\circ} \mathrm{C}\right)$ regimes used in model simulations for energetics of northern pike. Heavy line $=$ normal (Lac Ste. Anne); solid line $=27^{\circ} \mathrm{C}$ in July; broken line $=30^{\circ} \mathrm{C}$ in July; dashed line $=30^{\circ} \mathrm{C}$ June to August.

found for three Michigan lakes (Diana 1983b). Thus, this population does appear to be normal in terms of average growth rates. Temperature conditions for Lac Ste. Anne consistently follow the "normal" pattern I used in the simulation (Figure 1).

In order for the model to be useful, predicted maximum rations at a given temperature had to be calibrated to field conditions to account for prey availability, cropping efficiency, and other factors limiting ration. The simulations were done only for female fish, because sex-related differences in energy budgets of northern pike are large (Diana 1983a) and female maturation cycles are more costly in energy terms (and more likely to produce stunting). Field calibration was done in two stages: (1) the model was forced to fit measured monthly growth for 3-year-old northern pike from Lac Ste. Anne (Diana and Mackay 1979) by determining proportions of maximum ration actually required to meet the measured growth rates; then (2) this proportion was adjusted for ages 0 , 1 , and 2 so that each age reached its known size at the end of each year. The measured growths for each age-class included body and gonad growth. Specific values for proportion of maximum ration consumed are given in Table 1. Temperature regimes (Figure 1) for the normal cycle were used for this calibration. In addition to body growth, energy allocated to reproduction was determined as the proportion of total ingested energy that was deposited in gonad tissue each month for 3-yearold northern pike (Table 1) from Diana and Mackay (1979). These values were used for age-1 and -2 fish, whereas age- 0 fish were considered to be immature, allocating no energy to gonads. 
TABLE 1.-Monthly variables used to fit the model to normal growth data of northern pike (Diana and Mackay 1979), and simulated changes in northern pike ration caused by removal of large fish from the diet (from Diana 1979). Month 5 is May.

\begin{tabular}{rcccc}
\hline Month & $\begin{array}{c}\text { Body } \\
\text { weight }(\mathrm{g})\end{array}$ & $\begin{array}{c}\text { Propor- } \\
\text { tion of } \\
\text { maximum } \\
\text { ration } \\
\text { eaten }\end{array}$ & $\begin{array}{c}\text { Propor- } \\
\text { tion of } \\
\text { ration to } \\
\text { gonad } \\
\text { growth }\end{array}$ & $\begin{array}{c}\text { Propor- } \\
\text { tional } \\
\text { change in } \\
\text { ration by } \\
\text { removal of } \\
\text { large fish }\end{array}$ \\
\hline 5 & 850 & 0.42 & 0.01 & 0.91 \\
6 & 978 & 0.40 & 0.01 & 0.73 \\
7 & 1,101 & 0.38 & 0.01 & 0.78 \\
8 & 1,224 & 0.28 & 0.73 & 0.68 \\
9 & 1,235 & 0.28 & 0.77 & 0.52 \\
10 & 1,245 & 0.72 & 1.00 & 0.87 \\
11 & 1,245 & 0.90 & 1.13 & 0.87 \\
12 & 1,238 & 0.90 & 1.21 & 0.88 \\
1 & 1,225 & 0.84 & 1.00 & 0.88 \\
2 & 1,225 & 0.84 & 1.12 & 0.89 \\
3 & 1,220 & 0.50 & 0.00 & 0.90 \\
4 & 1,215 & 0.00 & 0.00 & \\
\hline
\end{tabular}

Once the model was calibrated to field conditions for Lac Ste. Anne, it was varied to test the effects of different thermal regimes and food limitation. (Because exploitation affects growth and survival, it could not be evaluated with the energetics approach alone.) Warmer thermal regimes (Figure 1) were used directly. These temperature regimes were considered to be simulations of fairly normal conditions for other lakes within the geographic range of northern pike. Food limitation through competition was simulated by assuming that competition reduced food intake by a constant $2.5,5$, or $10 \%$. This reduction could be caused by exploitation of food resources or behavioral shifts due to competition. Whereas metabolic costs might also rise during heavy competition, the net growth effect would be similar to that associated with reduced food consumption. Prey size structure was evaluated by removing white suckers and burbot from the rations determined by Diana (1979), then replacing them with average-size prey. This resulted in a monthly adjustment of ration values (Table 1). Adjustments for lack of large food were made to rations already corrected for calibrations (1) and (2) described earlier.

Simulations under each of these conditions were run for 3 years of life, starting with fish at $1 \mathrm{~g}$ in May of their first year. Comparisons of stunting were made by evaluating final body size under each condition.

\section{Results}

Proportions of maximum ration fitted to the Lac Ste. Anne growth curve indicated that northern pike consumed only $0-90 \%$ of their maximum possible ration each month (Table 1). Highest proportions occurred in fall and winter, whereas lowest proportions occurred in late summer and at spawning. In order to fit this model to younger fish, constants of 2.524 for age $0,0.86$ for age 1 , and 1.09 for age 2 had to be multiplied by the monthly corrected ration to meet the measured growth rate during those years. This adjustment indicated that weight exponents for ration $(-0.18$, from Bevelhimer et al. 1985) may be in error, as young fish would have to nearly triple their maximum consumption to produce the observed growth. Monthly reproductive allocations of energy requirred $0-121 \%$ of the ingested energy (Table 1), depending on season. Most allocations occurred over winter, and allocations greater than $100 \%$ indicated movement of stored energy from somatic tissue into gonads (Diana and Mackay 1979). Normal simulated northern pike populations reached $850 \mathrm{~g}$ by May of their third year (age $2+$ ), and had spawned twice by then.

Alteration of thermal regimes (Figure 1) had a large effect on growth (Figure 2A). The modeled optimum temperature for growth was $24^{\circ} \mathrm{C}$ for ages $0-2$. When summer temperatures were simulated to reach a maximum of $27^{\circ} \mathrm{C}$, final body weight was $94.8 \%$ higher than the final value for normal temperatures. However, simulated maximum temperatures exceeding $27^{\circ} \mathrm{C}$ reduced growth compared to the normal condition; $30^{\circ} \mathrm{C}$ for 1 month reduced final size by $38 \%$ compared to normal temperatures and $30^{\circ} \mathrm{C}$ for 3 months reduced final size by $58 \%$. Thus, very warm temperature conditions may cause stunting of northern pike.

Overall food limitation also produced simulated stunting (Figure 2B). Reductions in ration of $2.5,5$, and $10 \%$ reduced final body weight by 15 , 29 , and $51 \%$, respectively, compared to normal rations. Small reductions in feeding rate due to such factors as competition could have a very large effect on growth of northern pike.

Food limitations due to removal of large prey had the strongest effect on stunting: final body size was reduced $80 \%$ due to loss of large food items (Figure 2C). This occurred by a shift of only $7 \%$ of the total prey numbers eaten from large prey to average prey size.

A comparison of the three simulated mechanisms producing stunting is somewhat difficult, 


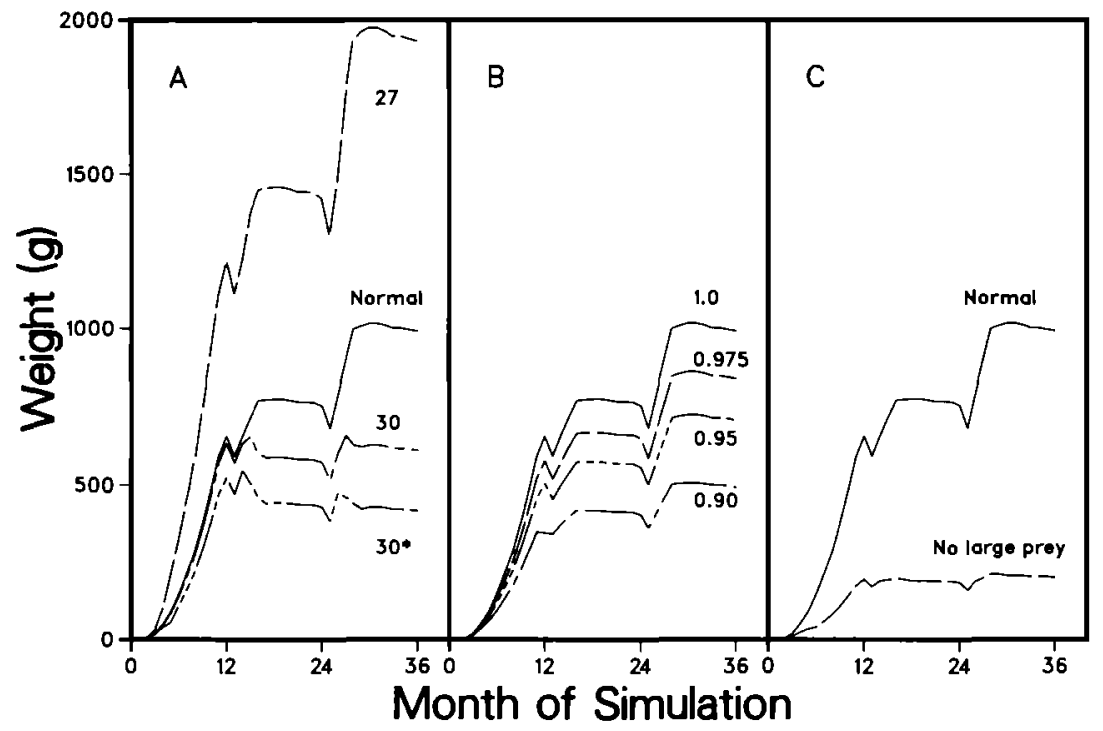

FIGURE 2.-Simulated body growth of northern pike over 3 years: (A) incorporating temperature regimes from Figure $1\left(27=27^{\circ} \mathrm{C}\right.$ in July; $30=30^{\circ} \mathrm{C}$ in July; $30^{*}=30^{\circ} \mathrm{C}$ June-August); (B) for normal temperature conditions with food consumption levels of $1.00,0.975,0.95$, and $0.90 ;(C)$ for normal temperature conditions with prey resources normal or with large-bodied prey absent.

because it depends on which level of competition or thermal input is used. Normal conditions for the model yielded a weight of $992 \mathrm{~g}$ after 36 months. A comparison of simulations based on the worst cases likely to occur in nature indicated that food-size factors have the largest potential to cause stunting ( $201 \mathrm{~g}$ fish after 36 months), whereas competition $(491 \mathrm{~g})$ and lack of thermal refuges $(417 \mathrm{~g})$ were nearly equal in importance.

\section{Discussion}

Stunting occurred in all simulations. The growth pattern could be misrepresented in the competition-based model because food resources were simulated to be a constant fraction of the normal ration, which would cause a continual monthly reduction in growth. However, both alteration of thermal histories and denial of large prey caused similar patterns of growth in spite of monthly alterations of the ration or temperature conditions.

Reductions in food intake due to competition or limited prey size resulted in the largest reductions in growth rate. Diana (1983b) found that only $7-42 \%$ of ingested energy appears in somatic tissue of northern pike, and that this percentage declines with age. Brett and Groves (1979) believed that catabolic processes of fish are satisfied first by ingested energy, and that excess energy produces somatic and gonad growth (i.e., scope for growth). Thus, the effect of reduced ration is exerted first on scope for growth, rather than equally throughout the energy budget, and growth must decline with even small reductions in ration. Of course, as growth (and body mass at age) declines, absolute costs of catabolic processes also decline, as these are functions of body mass.

The overall model is based on two major assumptions, and there are additional assumptions involved in each mechanism simulated. The first major assumption is that the proportion of maximum ration eaten each month is fixed and based on time, not temperature. Maximum ration increases with temperature (Bevelhimer et al. 1985), and was modeled accordingly. However, the proportion eaten is a factor to acount for foraging variables such as abundance of prey, capture efficiency, and handling time. The predator-prey relationship may be affected by temperature change (although there is no evidence for this at present), and extrapolation of values to a different temperature regime may cause errors.

The second major assumption in this model is that age at maturation is not altered in response to reduced energy intake. There is a large body of theoretical (see Roff 1983) and empirical (Wootton et al. 1980) literature that demonstrates alteration in maturation age in response to reduced food intake. Also, Diana (1983b) found age at 
maturation to be rather variable among northern pike. Because gonad allocations were considered to be a fixed proportion of the ration, which began at age 1 , the simulations were not allowed to forego current gonad growth for body growth, and thus to adapt to the limited ration available. This bias is probably most important in simulations that generated the smallest fish at 36 months, and body size for these populations would be larger if gonad growth were eliminated at age 1 . However, we have no empirical evidence for northern pike (or many other species) upon which to accommodate this trade-off between body growth and gonad growth.

Food limitation due to competition was simulated by assuming a constant reduction in food level across all ages and months. Because northern pike forage on animals that survive in nature for several years, food abundance does not vary seasonally as much as it does for other species (Dill 1983). However, it is most likely that competition for food is most severe when either availability is most limited or need is highest. This means that competition should cause the largest reductions in feeding over spring months and at young ages. My model, with constant food reduction, fails to include this. Thus, the ultimate pattern of growth may differ from this averaging of effects, but available evidence is insufficient to simulate seasonal or age-related effects. Relatively small (5\%) reductions in ration caused major reductions of growth, and it would be very difficult to quantify ration well enough in field populations to detect even a $10 \%$ reduction in food intake accurately.

Evaluation of thermal regimes relied on an additional assumption: that the energetics data used are typical of thermal responses for all northern pike populations. Bevelhimer et al. (1985) found optimal temperature for growth to be $25^{\circ} \mathrm{C}$ in their experiments and $24^{\circ} \mathrm{C}$ for their simulations. Casselman (1978) found optimal growth in the laboratory to be $18^{\circ} \mathrm{C}$ for northern pike from Ontario. Bevelhimer et al. (1985) attributed this difference to adaptation of their northern pike stock to warm water in hatchery ponds over 25 years. If this is true, then the importance of the thermal refuge mechanism may be underestimated in my study, because the simulation (based on "warm-adapted" fish) may not apply well to many natural populations. This points out the need to evaluate thermal responses of a species, including adaptations by populations to local temperature conditions.

Simulation of the lack of large prey was done by substituting average prey for large ones in diets observed by Diana (1979), then recalculating the ration. The underlying assumption was that the predator will not eat a larger number of small items to replace a single large item. Data from Diana (1979) indicate that over $60 \%$ of the northern pike with food in their stomachs had only one prey item, and less than $20 \%$ had more than two. Northern pike do not appear to compensate for meal size by eating more smaller items, but rather eat mainly one to two items per meal. Large items appear to be limited in availability to northern pike; less than $7 \%$ of the northern pike collected by Diana (1979) had large items in their stomachs, and $47 \%$ of the fish had empty stomachs. If compensation were likely to occur, the fish without large prey would have eaten more small items, not just one or two. However, this compensation may have occurred during the fall, when northern pike appeared to specialize on large numbers of youngof-year fish. Simulated ration during the fall was higher than summer values in relative terms (Table 1).

In conclusion, at least three ecological mechanisms may cause stunting in northern pike. Field work is needed to determine which may limit growth in a particular lake. In many cases, several factors may interact. Management actions such as manual removal of excess fish may reduce food limitation due to competition, but could do little for lakes where food size or thermal regimes cause stunting. Food size structure may be altered by introduction of new prey species or by habitat alterations to make prey more vulnerable or more abundant. Thermal regimes may be manipulated by regulating inflow to or outflow from the lake, or by recirculating the hypolimnion. A knowledge of mechanisms causing stunting will allow managers to tailor their actions to alleviate limiting factors, rather than to assume that the same limiting factor occurs for all populations of stunted northern pike.

\section{Acknowledgments}

I thank J. Burgett, P. Schneeberger, and B. Diana for their assistance in this work. This paper is contribution 466 of the Great Lakes Research Division, University of Michigan.

\section{References}

Bevelhimer, M. S., R. A. Stein, and R. F. Carline. 1985. Assessing significance of physiological differences among three esocids with a bioenergetics model. Canadian Journal of Fisheries and Aquatic Sciences 42:57-69. 
Brett, J. R., and T. D. D. Groves. 1979. Physiological energetics. Pages 279-352 in W. S. Hoar, D. J. Randall, and J. R. Brett, editors. Fish Physiology, volume 8. Academic Press, New York.

Burrough, R. J., and C. R. Kennedy. 1979. The occurrence and natural alleviation of stunting in a population of roach, Rutilus rutilus (L.). Journal of Fish Biology 15:93-110.

Carbine, W. F. 1944. Growth potential of northern pike (Esox lucius). Papers of the Michigan Academy of Sciences, Arts and Letters 30:205-220.

Casselman, J. M. 1978. Effects of environmental factors on growth, survival, activity, and exploitation of northern pike. American Fisheries Society Special Publication 11:114-128.

Diana, J. S. 1979. The feeding pattern and daily ration of a top carnivore, the northern pike (Esox lucius). Canadian Journal of Zoology 57:2121-2127.

Diana, J. S. 1982. An experimental analysis of the metabolic rate and food utilization of northern pike. Comparative Biochemistry and Physiology A, Comparative Physiology 71:395-399.

Diana, J. S. 1983a. An energy budget for northern pike (Esox lucius). Canadian Journal of Zoology 61:19681975.

Diana, J. S. 1983b. Growth, maturation, and production of northern pike in three Michigan lakes. Transactions of the American Fisheries Society 112 : $38-46$.

Diana, J. S., and W. C. Mackay. 1979. Timing and magnitude of energy deposition and loss in the body, liver, and gonads of northern pike (Esox lucius). Journal of the Fisheries Research Board of Canada 36:481-487.

Dill, L. M. 1983. Adaptive flexibility in the foraging behavior of fishes. Canadian Journal of Fisheries and Aquatic Sciences 40:398-408.

Fryer, J. N., and H. A. Bern. 1979. Growth hormone binding to tissues of normal and stunted juvenile coho salmon, Oncorhynchus kisutch. Joumal of Fish Biology 15:535-544.

Headrick, M. R. 1985. Bioenergetic constraints on habitat use by northern pike (Esox lucius) in Ohio reservoirs. Doctoral dissertation. Ohio State University, Columbus.

Healey, M. C. 1975. Dynamics of exploited whitefish populations and their management with special ref- erence to the Northwest Territories. Journal of the Fisheries Research Board of Canada 32:427-448.

Kempinger, J. J., and R. F. Carline. 1978. Dynamics of the northern pike population and changes that occurred with a minimum size limit in Escanaba Lake, Wisconsin. American Fisheries Society Special Publication 11:382-389.

Laarman, P. W., J. C. Schneider, and H. Gowing. 1981. Methods in age and growth analyses of fish. Pages VI-A-4-1 to VI-A-4-17 in J. W Merna, J. C. Schneider, G. R. Alexander, W. D. Alward, and R. L. Eshenroder, editors. Manual of fisheries survey methods. Michigan Department of Natural Resources, Fishery Management Report 9, Lansing.

Linfield, R. S. J. 1979. Changes in the rate of growth in a stunted roach Rutilus rutilus population. Journal of Fish Biology 15:299-308.

MDNR (Minnesota Department of Natural Resources). 1983. Lake management planning guide. Fisheries Division, Special Publication 132, St. Paul.

Miller, R. B., and W. A. Kennedy. 1948. Pike (Esox lucius) from four northern Canadian lakes. Journal of the Fisheries Research Board of Canada 7:190199.

Noble, R. L. 1980. Management of lakes, reservoirs, and ponds. Pages 265-296 in R. T. Lackey and L. A. Nielsen, editors. Fisheries management. Wiley, New York.

Reimers, N. 1979. A history of a stunted brook trout population in an alpine lake: a life span of 24 years. California Fish and Game 65:195-215.

Ricker, W. E. 1981. Changes in the average size and average age of Pacific salmon. Canadian Journal of Fisheries and Aquatic Sciences 38:1636-1656.

Roff, D. A. 1983. An allocation model of growth and reproduction in fish. Canadian Joumal of Fisheries and Aquatic Sciences 40:1395-1407.

Webb, P. W. 1978. Partitioning of energy into metabolism and growth. Pages 184-214 in S. D. Gerking, editor. Ecology of freshwater fish production. Wiley, New York.

Wootton, R. J., J. R. M. Allen, and S. J. Cole. 1980. Energetics of the annual reproductive cycle in female sticklebacks, Gasterosteus aculeatus L. Journal of Fish Biology 17:387-394.

Received November 14, 1986 Accepted June 27, 1987 